\title{
LOWER LEG DEFORMITY CORRECTION USING ILIZAROV DEVICE IN DR SOETOMO GENERAL HOSPITAL SURABAYA: A CASE SERIES
}

\author{
Jeffry Andrianus ${ }^{1 *}$, Citra Ahdi Prasetya ${ }^{2}$ \\ ${ }^{1}$ Senior Consultant of Orthopaedic and Traumatology, Faculty of Medicine, Universitas \\ Airlangga / Dr Soetomo Hospital, Surabaya \\ ${ }^{2}$ Resident in Department of Orthopaedic and Traumatology, Faculty of Medicine, Universitas \\ Airlangga / Dr Soetomo General Hospital, Surabaya \\ *Corresponding Author: Jeffry Andrianus, Department of Orthopaedic and Traumatology, \\ Faculty of Medicine, Universitas Airlangga / Dr Soetomo Hospital, Surabaya, Jl. Mayjen Prof. \\ Dr. Moestopo 6-7, Surabaya 60286 \\ E-mail: drjuportho@icloud.com
}

\section{ABSTRAK}

Latar Belakang: Limb deformity, terutama lower limb merupakan kelainan yang banyak kita jumpai dalam praktik sehari-hari. Penyebab dari limb deformity secara umum dapat kita kelompokkan berdasarkan penyebab (kongenital, developmental, post trauma); geometri (angulasi, rotasi, shortening); severity dan progression. Pada kasus-kasus deformitas yang kompleks dan berat, pilihan terapinya antara lain adalah gradual correction menggunakan ilizarov system. Keunggulan gradual deformity correction dengan Ilizarov device ini antara lain (1) mengurangi risiko cedera neurovaskuler, (2) gangguan yang minimal terhadap soft tissue (3) bisa melakukan koreksi multiplanar dan multidireksional.

Kasus: Telah dilakukan 11 koreksi deformitas menggunakan ilizarov device selama periode Januari 2013 - September 2017. Data klinis evaluasi pasien didapatkan secara retrospektif dari rekam medis pasien. Sembilan pasien dilakukan pemasangan Ilizarov device untuk bone lengthening, dan 2 pasien dilakukan pemasangan Ilizarov device untuk bone transport. Hasil koreksi dievaluasi untuk skor kondisi tulang dan skor fungsional berdasarkan ASAMI Scoring System.

Hasil: Dari sebelas pasien telah dilakukan pemasangan Ilizarov device untuk koreksi deformitas pada extremitas bawah, sembilan pasien telah selesai dilakukan koreksi dan telah dilakukan pelepasan ilizarov device. Dua pasien tidak dapat dilakukan evaluasi karena terjadi kegagalan sistem (failure) ilizarov device dan harus diganti dengan fiksasi yang lain. Evaluasi menggunakan ASAMI score pada 9 pasien yang telah selesai dilakukan pemasangan Ilizarov, didapatkan 9 pasien dengan skor good untuk bone dan 7 dengan skor exellent untuk fungsional. Kesimpulan: Ilizarov system dapat digunakan untuk koreksi deformitas ekstremitas bawah dengan hasil yang cukup menjanjikan.

Kata kunci: lower leg deformity, Ilizarov, limb lengthening

\begin{abstract}
Background: limb deformity, especially lower leg deformity is a common case in orthopaedic practice. Limb deformity can be classified according to cause (Congenital, developmental, post trauma), geometry (angulation, rotation, shortening), severity and progression. In severe and complex deformity, the treatment choice is gradual correction using Ilizarov system. Benefit of
\end{abstract}


the gradual correction using Ilizarov system are: (1) reduce the risk of neurovascular injury, (2) minimal soft tissue disturbance, (3) multiplanar and multidirectional correction.

Cases: We have performed 11 deformity correction using ilizarov device during january 2013 September 2017. Evaluation data was obtained retrospectively from medical record. Nine patients were managed by Ilizarov device for bone lengthening indication and 2 patients for bone transport indication. The treatment result was evaluated using ASAMI scoring system for bone condition and functional condition.

Results: Elevent patients were managed by Ilizarov system for gradual deformity correction. Nine patients already finished the treatment and the frame was removed. We cannot evaluate two patients because the correction was not finished. The ilizarov device was changed with other fixation because implant failure during correction phase. Evaluation using ASAMI score showed good bone score result for 9 patients and 7 excellent result for functional score.

Conclusion: Ilizarov system has a promising result to correct lower limb deformity patients in Dr Soetomo General Hospital.

Keywords: lower leg deformity, Ilizarov, limb lengthening

\section{PENDAHULUAN}

Deformitas pada ekstremitas, terutama pada ekstermitas bawah merupakan kelainan yang banyak kita jumpai dalam praktik sehari-hari. Deformitas tungkai atau ekstremitas bawah (lower limb deformity) secara umum dapat kita kelompokkan berdasarkan penyebab (congenital, developmental, post trauma); berdasarkan geometri (angulasi, rotasi, shortening); severity dan progression..$^{1-3}$

Beberapa modalitas yang dapat digunakan untuk terapi pada kasus deformitas antara lain stretching and splinting, soft tissue procedure, dan bone correction. ${ }^{2}$ Pada kasus-kasus deformitas yang kompleks dan berat, pilihan terapinya antara lain adalah gradual correction menggunakan Ilizarov system. ${ }^{1}$

Keunggulan gradual deformity correction dengan ini antara lain (1) mengurangi risiko cedera neurovaskuler, (2) gangguan yang minimal terhadap soft tissue dan (3) bisa melakukan koreksi multiplanar. ${ }^{1,2}$

Prinsip dasar koreksi deformitas menggunakan ilizarov device adalah adanya compression - distraction osteogenesis pada tulang yang dilakukan koreksi dan gradual stretching pada jaringan lunak (soft tissue). Pada kondisi distraksi, akan terbentuk tulang dan soft tissue baru. Pada sistem ini, distraksi memegang peranan penting dalam proses maturasi jaringan, sehingga Ilizarov system ini baru dilepas setelah tulang dan 
Laporan Kasus

Vol 7 No. 1, April 2018

ISSN 2460-8742

http://journal.unair.ac.id/ORTHO@journal-orthopaedi-and-traumatology-surabaya-media-104.html

jaringan baru yang terbentuk cukup kuat untuk secara mandiri menahan beban fisiologis. ${ }^{1}$

\section{Distraction Osteogenesis}

Menggunakan Ilizarov System

Ilizarov memperkenalkan metode osteogenesis baru yang dikenal sebagai distraksi/distraction osteogenesis ${ }^{4}$, sebuah metode klinis yang unik yang bertujuan merangsang pertumbuhan tulang yang mengalami defisiensi baik pada panjang, lebar maupun kelurusannya (alignment), atau pada tulang yang terdapat celah, tulang yang nonunion misalnya pada bone loss pada osteomyelitis kronik. Disini terjadi distraksi mekanis secara gradual dari kortikotomi/osteotomi dengan energi yang rendah yang secara spontan memproduksi tulang baru dari segmen tulang yang dilakukan kortikotomi/ osteotomi, yang berasal dari tulang aslinya yang terus menerus secara cepat mengalami remodelling menuju bentuk struktur normal, meski pada tulang orang dewasa.

\section{Nonunion Fracture}

Ilizarov method juga banyak digunakan pada kasus-kasus non union, terutama pada kasus-kasus dengan infected non union dengan bone loss. Tatalaksana infected nonunion secara umum adalah (1) pelepasan/removal dari semua implan, (2) debridement yang agresif dan membuang semua jaringan yang mati/infected, (3) pengambilan contoh jaringan untuk kultur, (4) aplikasi antibiotika lokal pada daerah infeksi. ${ }^{5}$

Tindakan debridement dan pembuangan jaringan mati ini seringkali akan meninggalkan celah atau gap pada tulang dan jaringan mati. Celah ini dapat dikoreksi dengan menggunakan kortikotomi dan bone transport dengan Ilizarov system. Penggunaan Ilizarov system ini memungkinkan untuk didapatkan stabilitas tulang dan soft tissue yang dibutuhkan untuk proses penyembuhan/healing, early weight bearing menggunakan crutch dan bone transport untuk mengisi bone defect akibat infeksi dan debridement yang dilakukan. ${ }^{5,6}$

\section{Peralatan}

Perakitan perangkat ini dapat dilakukan dengan banyak variasi, tergantung kebutuhan dan rencana koreksi yang diperlukan terhadap masing-masing pasien. Secara umum desain Ilizarov device dapat dilihat pada Gambar 1. 


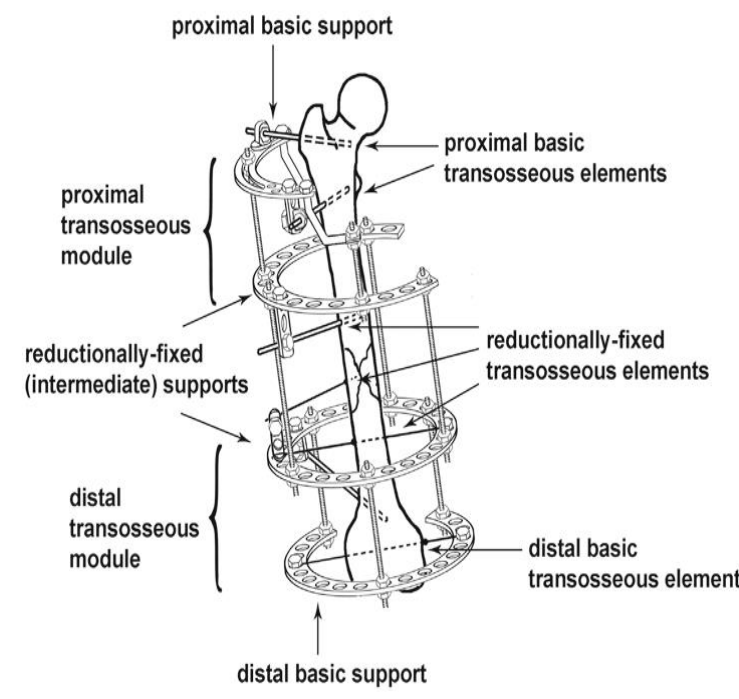

Gambar 1. Desain standar perakitan perangkat Ilizarov ${ }^{7}$

Untuk mencapai kontrol posisi yang ideal dari fragmen tulang, perangkat eksternal fiksasi yang dipasang sebaiknya dapat memberikan ruang pergerakan pada fragmen tulang pada 3 bidang (plane) sekaligus, baik pada metode manuver reduksi langsung (satu tahap) atau reduksi secara gradual dan progresif. ${ }^{7.8}$

\section{LAPORAN KASUS}

Semua pasien yang dilakukan pemasangan Ilizarov device di RSUD Dr.
Soetomo Surabaya selama periode Januari 2015 sampai Agustus 2017 dilakukan evaluasi berdasarkan diagnosa awal, indikasi untuk dilakukan pemasangan Ilizarov device dan kondisi pasca dilakukan koreksi (Tabel 1). Data diperoleh secara retrospektif cari rekam medis pasien. Operasi dilakukan oleh satu orang operator yaitu senior konsultan divisi lower extremity RSUD Dr. Soetomo Surabaya.

Dari 11 pasien yang dilakukan pemasangan Ilizarov device, 9 pasien telah selesai dilakukan koreksi deformitas, 2 pasien dilakukan penggantian alat karena alasan implant failure pada Ilizarov device yang dipasang.

Evaluasi hasil secara keseluruhan dari pemasangan Ilizarov device ini dilakukan menggunakan Association for the Study and Aplication of Methods of Ilizarov (ASAMI) Scoring System yang dapat dilihat pada Gambar 2 dan 3.

Tabel 1. Daftar Pasien yang dilakukan pemasangan Iliarov device di RSUD Dr Soetomo Surabaya selama Januari 2015 - Agustus 2017. Data evaluasi pasien diambil secara retrospektif dari data rekam medis.

\begin{tabular}{|c|c|c|c|c|c|c|}
\hline No & Identitas & Diagnosis & Kondisi Awal & treatment & Post koreksi & Komplikasi \\
\hline 1 & A /L/13 th & $\begin{array}{l}\text { Malunion distal } \\
\text { femur post traktur } \\
\text { patologis distal } \\
\text { femur ec } \\
\text { Hemangioma }\end{array}$ & $\begin{array}{l}\text { - Post } \\
\text { massive } \\
\text { allograf } \\
\text { - Post fail } \\
\text { correction } \\
\text { dengan } \\
\text { Wagner }\end{array}$ & $\begin{array}{l}\text { pemasangan } \\
\text { Illizarov device } \\
\text { (Sept 2014 s/d } \\
\text { april 2015) } \\
\text { - Angulasi dikoreksi } \\
\text { pada awal } \\
\text { pemasangan } \\
\text { Ilizarov }\end{array}$ & $\begin{array}{l}\text { Leg length } \\
\text { Kanan=Kiri } \\
\text { Keluhan (-) } \\
\text { ADL dbn }\end{array}$ & $\begin{array}{l}\text { pin tract } \\
\text { infection }\end{array}$ \\
\hline
\end{tabular}


Laporan Kasus

Vol 7 No. 1, April 2018

ISSN 2460-8742

http://journal.unair.ac.id/ORTHO@journal-orthopaedi-and-traumatology-surabaya-media-104.html

\begin{tabular}{|c|c|c|c|c|c|c|}
\hline & & & $\begin{array}{l}\text { - } \text { LLD } 6 \mathrm{~cm} \\
(\mathrm{Ka}<\mathrm{Ki}) \\
\text { - } \text { varus } \\
\text { deformity }\end{array}$ & $\begin{array}{l}\text { - Bone lengthening } \\
\text { selama } 3 \text { bulan (1 } \\
\mathrm{mm} / \text { hari) }\end{array}$ & & \\
\hline 2 & $\mathrm{~A} / \mathrm{L} / 37 \mathrm{th} /$ & $\begin{array}{l}\text { Open fraktur tibia } \\
\text { fibula Sinistra } 1 / 3 \\
\text { distal grade 3B } \\
\text { dengan bone loss. }\end{array}$ & $\begin{array}{l}\text { - Bone Loss } \\
\text { - leg length } \\
\text { discrepancy } \\
6 \mathrm{~cm}\end{array}$ & $\begin{array}{l}\text { pemasangan } \\
\text { Illizarov device } \\
\text { (Desember } 2013 \text { - } \\
\text { Juni 2014) } \\
\text { - bone lengthening } \\
\text { dan bone transport } \\
\text { selama } 4 \text { bulan }\end{array}$ & $\begin{array}{l}\text { LLD } 0,5 \mathrm{~cm} \\
\text { Kiri < kanan } \\
\text { Sol untuk } \\
\text { koreksi LLD } \\
\text { Keluhan (-), } \\
\text { ADL dbn }\end{array}$ & $\begin{array}{l}\text { pin tract } \\
\text { infection }\end{array}$ \\
\hline 3 & W/L/29 th & $\begin{array}{l}\text { Malunion tibia } \\
\text { fibula }\end{array}$ & $\begin{array}{l}\text { angulasi } 90^{\circ} \\
\text { leg length } \\
\text { discrepancy } \\
5 \mathrm{~cm}\end{array}$ & $\begin{array}{l}\text { pemasangan } \\
\text { Illizarov device } \\
\text { (Juli 2015 - Maret } \\
2016 \text { ) } \\
\text { - koreksi angulasi } \\
\text { dan shortening } \\
\text { - Interlocking nail } \\
\text { tibia }\end{array}$ & $\begin{array}{l}\text { Post gradual } \\
\text { correction : } \\
\text { AP angulasi } \\
1^{\circ} \text {, lateral } \\
\text { angulasi } 5^{\circ} .\end{array}$ & $\begin{array}{l}\text { pin tract } \\
\text { infection }\end{array}$ \\
\hline 4 & $\mathrm{R} / \mathrm{L} / 31$ th & $\begin{array}{l}\text { Neglected Open } \\
\text { fraktur Tibia } \\
\text { Fibula Sinistra 1/3 } \\
\text { distal }\end{array}$ & $\begin{array}{l}\text { LLD } 3 \mathrm{~cm} \\
\text { bone loss } \\
\text { distal tibia }\end{array}$ & $\begin{array}{l}\text { pemasangan } \\
\text { Illizarov device } \\
\text { (maret 2015- } \\
\text { Agustus 2015) } \\
\text { - bone lengthening } \\
\text { selama 1 bulan }\end{array}$ & $\begin{array}{l}\text { LLD (-) } \\
\text { Keluhan (-), } \\
\text { ADL dbn }\end{array}$ & $\begin{array}{l}\text { - pin tract } \\
\text { infection }\end{array}$ \\
\hline 5 & $\mathrm{AS} / \mathrm{L} / 14$ th & $\begin{array}{l}\text { Malunion tibia } \\
\text { post fibula pro } \\
\text { tibia ec Bone Loss } \\
\text { ec Osteomyelitis } \\
\text { kronis tibia } \\
\text { Dextra. }\end{array}$ & LLD $10 \mathrm{~cm}$ & $\begin{array}{l}\text { pemasangan } \\
\text { Illizarov device } \\
\text { (Mei 2014-Mei } \\
\text { 2016) } \\
\text { - bone lengthening } \\
\text { selama } 6 \text { bulan }\end{array}$ & $\begin{array}{l}\text { LLD (-) } \\
\text { Kaku pada } \\
\text { sendi lutut } \\
\text { Limitasi ADL } \\
\text { (Mild) }\end{array}$ & $\begin{array}{l}\text { - pin tract } \\
\text { infection } \\
\text { joint } \\
\text { stiffness }\end{array}$ \\
\hline 6 & $\mathrm{Z} / \mathrm{L} / 32$ th & $\begin{array}{l}\text { Infected Nonunion } \\
\text { intercondyler } \\
\text { femur Dextra post } \\
\text { CBP femur }\end{array}$ & $\begin{array}{l}\text { LLD } 4 \mathrm{~cm} \text {, } \\
\text { Varus } \\
\text { deformity }\end{array}$ & $\begin{array}{l}\text { - } \text { pemasangan } \\
\text { Illizarov device } \\
\text { (Mei 2014) } \\
\text { - lengthening } 1 \\
\text { bulan } \rightarrow \text { failed }\end{array}$ & $\begin{array}{l}\text { Implant } \\
\text { failure } \\
\text { Diganti } \\
\text { dengan } \\
\text { imternal } \\
\text { fiksasi }\end{array}$ & $\begin{array}{ll}\text { - } & \text { pin tract } \\
\text { infection } \\
\text { - implant } \\
\text { failure }\end{array}$ \\
\hline 7 & GR/L/13 th & $\begin{array}{l}\text { Malunion femur } \\
\text { Dextra }\end{array}$ & LLD $10 \mathrm{~cm}$ & $\begin{array}{l}\text { pemasangan } \\
\text { Illizarov device } \\
\text { (April 2015 - Juli } \\
\text { 2016) }\end{array}$ & $\begin{array}{l}\text { LLD (-) } \\
\text { Keluhan (-), } \\
\text { ADL dbn }\end{array}$ & 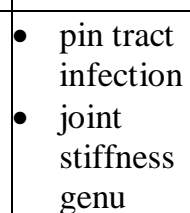 \\
\hline 8 & IB/L/20 th & $\begin{array}{l}\text { Open fraktur tibia } \\
\text { fibula Dextra post } \\
\text { dengan Bone Los }\end{array}$ & $\begin{array}{l}\text { Bone gap } 8 \\
\mathrm{~cm}\end{array}$ & $\begin{array}{l}\text { pemasangan } \\
\text { Illizarov device } \\
\text { untuk bone } \\
\text { transport (April } \\
2015 \text { - Juni 2016) } \\
\text { - Interlocking nail } \\
\text { tibia }\end{array}$ & $\begin{array}{l}\text { LLD (-) } \\
\text { Keluhan (-), } \\
\text { ADL dbn }\end{array}$ & $\begin{array}{l}\text { pintract } \\
\text { infection }\end{array}$ \\
\hline 9 & $\mathrm{M} / \mathrm{P} / 30$ th & $\begin{array}{l}\text { Nonunion cruris } \\
\text { post External } \\
\text { fiksasi ec Open } \\
\text { fraktur tibia fibula } \\
\text { grade IIIB }\end{array}$ & b $\operatorname{LLD} 4 \mathrm{~cm}$ & $\begin{array}{l}\text { pemasangan } \\
\text { Illizarov device } \\
\text { (Maret 2014- } \\
\text { Oktober 2014) } \\
\text { - bone lengthening } 3 \\
\text { bulan }\end{array}$ & $\begin{array}{l}\text { LLD (-) } \\
\text { ADL dbn } \\
\text { Keluhan (-) }\end{array}$ & $\begin{array}{l}\text { pin tract } \\
\text { infection }\end{array}$ \\
\hline
\end{tabular}


Laporan Kasus

Vol 7 No. 1, April 2018

ISSN 2460-8742

http://journal.unair.ac.id/ORTHO@journal-orthopaedi-and-traumatology-surabaya-media-104.html

\begin{tabular}{|c|l|l|l|l|l|l|}
\hline 10 & S/L/20 th & $\begin{array}{l}\text { Infected Nonunion } \\
\text { tibia post Open } \\
\text { fraktur Tibia } \\
\text { Fibula Dextra 1/3 } \\
\text { distal dengan bone } \\
\text { loss }\end{array}$ & $\begin{array}{l}\text { LLD (-) } \\
\text { Bone gap 7 } \\
\mathrm{cm}\end{array}$ & $\begin{array}{l}\text { pemasangan } \\
\text { Illizarov device } \\
\text { (Februari 2015) } \\
\text { bone transport } \\
\text { selama 4 bulan }\end{array}$ & $\begin{array}{l}\text { LLD (-) } \\
\text { ADL dbn } \\
\text { Keluhan (-) }\end{array}$ & $\bullet \begin{array}{l}\text { Pin Tract } \\
\text { Infection }\end{array}$ \\
\hline 11 & NN/P/53 th & $\begin{array}{l}\text { Infected Nonunion } \\
\text { distal femur } \\
\text { Dextra post ORIF }\end{array}$ & $\begin{array}{l}\text { LLD 2 cm } \\
\text { false } \\
\text { movement } \\
(+)\end{array}$ & $\begin{array}{l}\text { pemasangan } \\
\text { Illizarov device }+ \\
\text { fibular graft } \\
\text { (Feb 2015 - } \\
\text { September 2015) }\end{array}$ & $\begin{array}{l}\text { Implant } \\
\text { failure. } \\
\text { Pathologic } \\
\text { fracture } \\
\text { proximal dari } \\
\text { pin insertion }\end{array}$ & $\bullet \begin{array}{l}\text { pin tract } \\
\text { infection } \\
\text { stiffness } \\
\text { genu }\end{array}$ \\
\hline
\end{tabular}

\begin{tabular}{|c|c|c|}
\hline Bone Results & ts Description & Score \\
\hline Excellent & Union, no infection, deformity $<7$, limb length discrepancy $<2.5 \mathrm{~cm}$ & 10 \\
\hline Good & Union + any two of the following: absence of infection $<7$ deformity and limb length inequality of $<2.5 \mathrm{~cm}$ & 2 \\
\hline Fair & Union + only one of the following: absence of infection, deformity $<7$ and limb length inequality $<2.5 \mathrm{~cm}$ & 0 \\
\hline Poor & Non union/refracture/union + infection + deformity $>7+$ limb length inequality $>2.5 \mathrm{~cm}$ & 0 \\
\hline Functional & Description & Score \\
\hline Excellent & $\begin{array}{l}\text { Active, no limp, minimum stiffness (loss of }<15 \text { knee extension/ }<15 \text { dorsiflexion of ankle), no reflex sympathet- } \\
\text { ic dystrophy (RSD), insignificant pain }\end{array}$ & 6 \\
\hline Good & Active, with one or two of the following: limp, stiffness, RSD ${ }^{\mathrm{a}}$, significant pain & 4 \\
\hline Fair & Active, with three or all of the following: limp, stiffness, RSD ${ }^{\mathrm{a}}$, significant pain & 0 \\
\hline Poor & Inactive (unemployment or inability to perform daily activities because of injury) & 2 \\
\hline Failures & Amputation & 0 \\
\hline
\end{tabular}

Gambar 2. Scoring menurut Association for the Study and Aplication of Methods of Ilizarov (ASAMI), dikutip dalam bentuk asli dari website ASAMI.

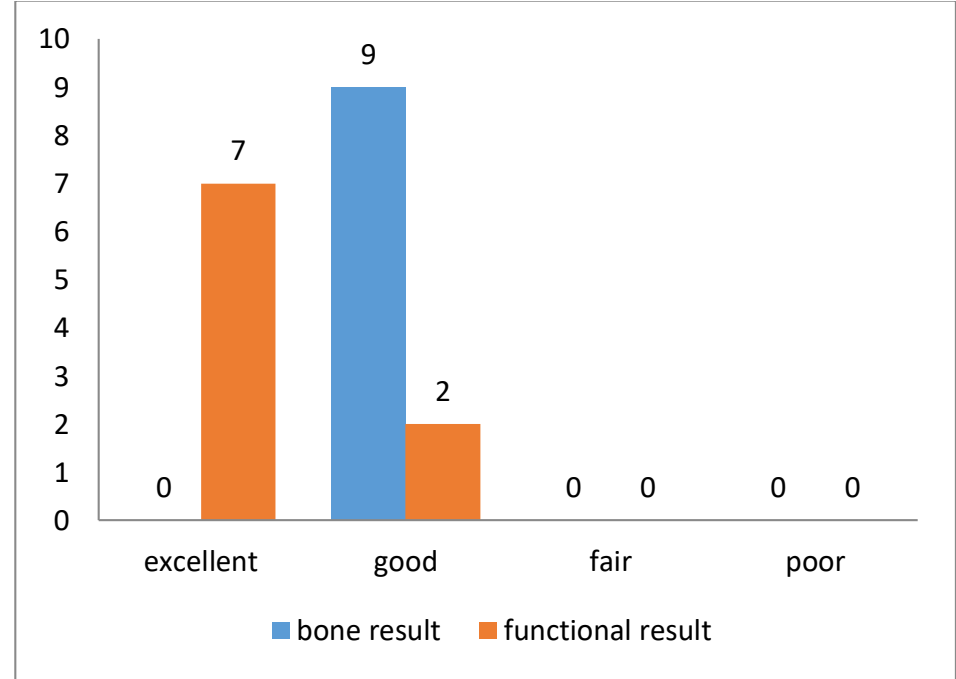

Gambar 3. Grafik evaluasi hasil terapi menggunakan ASAMI skor pada 9 pasien yang telah menyelesaikan proses koreksi menggunakan Ilizarov device. Didapatkan hasil good untuk bone scoring pada 9 pasien (100\%) dan hasil excellent untuk functional scoring pada 9 pasien $(100 \%)$. Dua pasien tidak dilakukan evaluasi (kasus 6 dan 11) karena proses koreksi tidak selesai. 


\section{DISKUSI}

Koreksi deformitas pada ekstremitas bawah dapat menggunakan beberapa metode, salah satu pilihan adalah menggunakan Ilizarov device. Keunggulan gradual correction deformitas menggunakan Ilizarov device antara lain (1) mengurangi risiko cedera neurovaskuler, (2) gangguan yang minimal terhadap soft tissue (3) bisa melakukan koreksi multiplanar dan multidirectional. ${ }^{2}$

Pathania et al melakukan koreksi deformitas menggunakan Ilizarov pada pasien dengan deformitas ekstremitas bawah (New Delhi, 2001-2003). Enam pasien dengan Congenital talipes equinovarus, delapan pasien dengan fixed flexion deformity sendi lutut, empat pasien dengan equinus deformity ankle, 2 pasien dengan malunion fraktur tibia.(2) Dari 20 pasien didapatkan 16 pasien $(80 \%)$ dengan hasil excellent menurut skor ASAMI, 4 pasien (20\%) dengan mild recurrency, namun semua pasien mampu melakukan aktivitas sehari-hari dengan mandiri. ${ }^{2}$

Shahid et al melakukan penelitian di Queen Elizabeth Hospital, Birmingham (Maret 2009-Agustus 2010) pada 12 pasien dengan infected nonunion tibia. Dari penelitian ini didapatkan semua pasien mengalami union dengan rata-rata waktu penyembuhan 46 minggu (24-70 minggu). Evaluasi menggunakan ASAMI score didapatkan 10 pasien dengan hasil excellent dan 2 pasien dengan hasil scoring good. ${ }^{7}$

Evaluasi pada studi ini didapatkan hasil yang serupa dengan studi terdahulu. Dari 11 pasien telah dilakukan ilizarov procedure untuk koreksi deformitas pada ekstremitas bawah, 9 pasien telah selesai dilakukan koreksi dan telah dilakukan pelepasan ilizarov device. Dua pasien (kasus 6 dan 11) koreksi deformitas dengan Ilizarov device tidak dilanjutkan karena frame dan rod yang bengkok saat dilakukan pemanjangan (lengthening). Kondisi ini kemungkinan disebabkan oleh kekuatan metal implant yang tidak bagus sehingga tidak mampu menahan gaya saat dilakukan pemanjangan.

Semua pasien yang telah selesai proses koreksinya ( 9 orang) atau 9 dari total 11 pasien $(81,8 \%)$ berhasil mencapai target terapi pemasangan Ilizarov device yaitu lengthening (discrepancy $<1 \mathrm{~cm}$ ) dan bone transport serta tidak didapatkan keluhan saat berjalan (Gambar 6-8). Hasil evaluasi masing-masing komponen ASAMI Skor dapat dilihat pada gambar grafik 4 dan 5 .

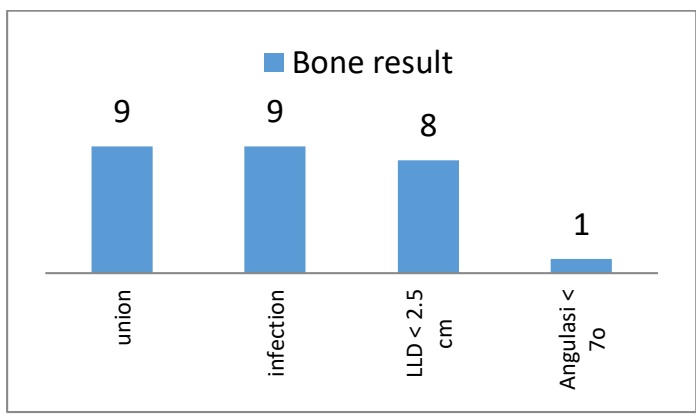

Gambar 4. Grafik evaluasi komponen bone skoring pada 9 pasien. Didapatkan hasil 
Laporan Kasus

Vol 7 No. 1, April 2018

ISSN 2460-8742

http://journal.unair.ac.id/ORTHO@journal-orthopaedi-and-traumatology-surabaya-media-104.html

union pada 9 pasien $(100 \%)$ dan tidak didapatkan deformitas (LLD $<2.5 \mathrm{~cm} /$ angulasi $<7^{\circ}$ ) pada 9 pasien $(100 \%)$.

Namun didapatkan hasil adanya pintract infection pada 9 pasien (100\%).

\begin{tabular}{|c|c|c|c|}
\hline \multicolumn{4}{|c|}{ fungsional } \\
\hline & 2 & & \\
\hline 0 & & 0 & 0 \\
\hline 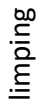 & 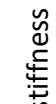 & ڤ్વે & 志 \\
\hline
\end{tabular}

Gambar 5. Grafik evaluasi komponen functional scoring pada 9 pasien. Tidak didapatkan adanya limping, reflex sympathetic distrophy dan nyeri yang signifikan pada semua pasien. Didapatkan joint stiffness pada 2 pasien (22,2\%).

Keluhan yang seringkali muncul dari pasien yang dilakukan koreksi dengan Ilizarov device adalah alat yang berat dan tidak praktis untuk melakukan aktivitas sehari-hari dan adanya infeksi dari pin tract.

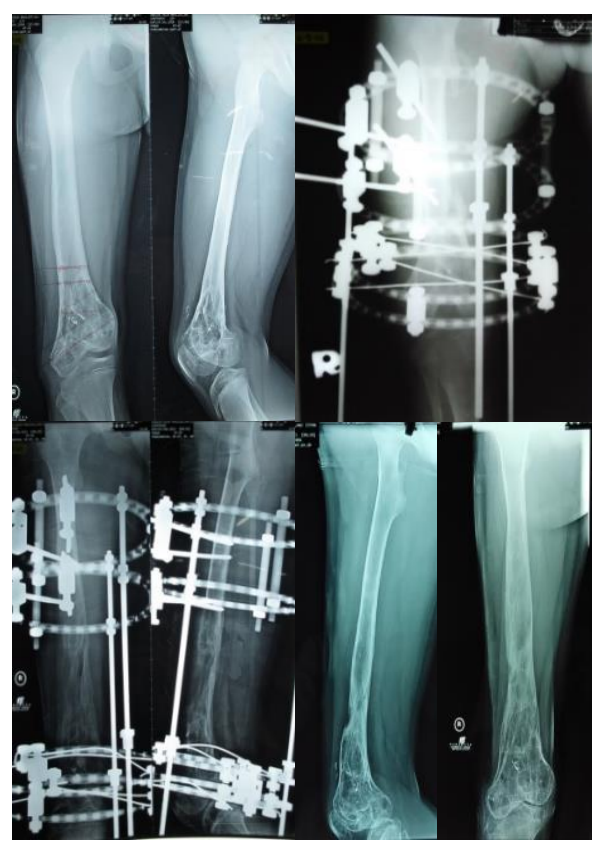

Gambar 6. Pasien 1 (Tn A/13 th) dengan shortening dan angulasi yang dilakukan koreksi menggunakan Ilizarov device (gambar atas) menunjukkan hasil yang bagus setelah koreksi selesai dan Ilizarov device dilepas (gambar bawah)

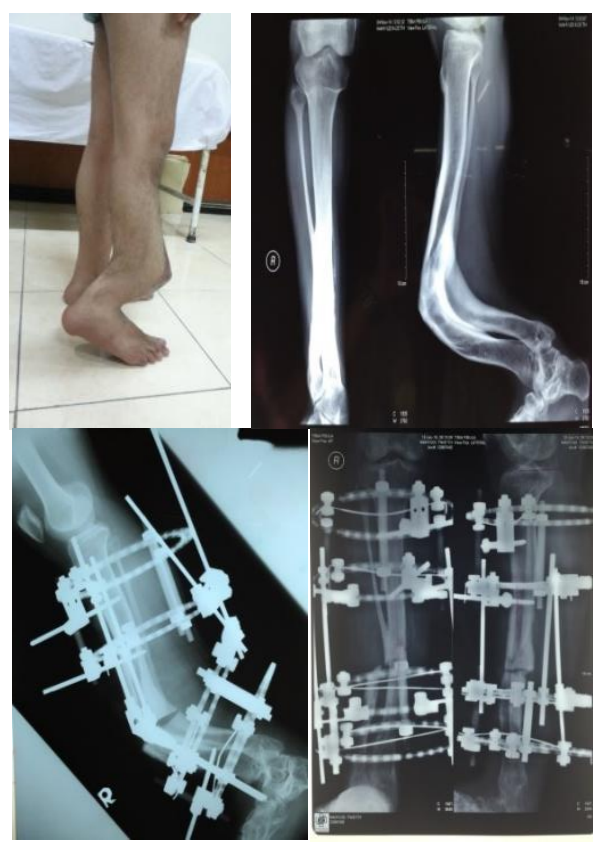

Gambar 7. Kondisi awal Pasien 3 (Tn W/29 th) dengan severe deformity (angulasi dan shortening) sebelum dilakukan koreksi (gambar atas) menunjukkan hasil yang bagus setelah dilakukan koreksi gradual dengan Ilizarov device (gambar bawah)
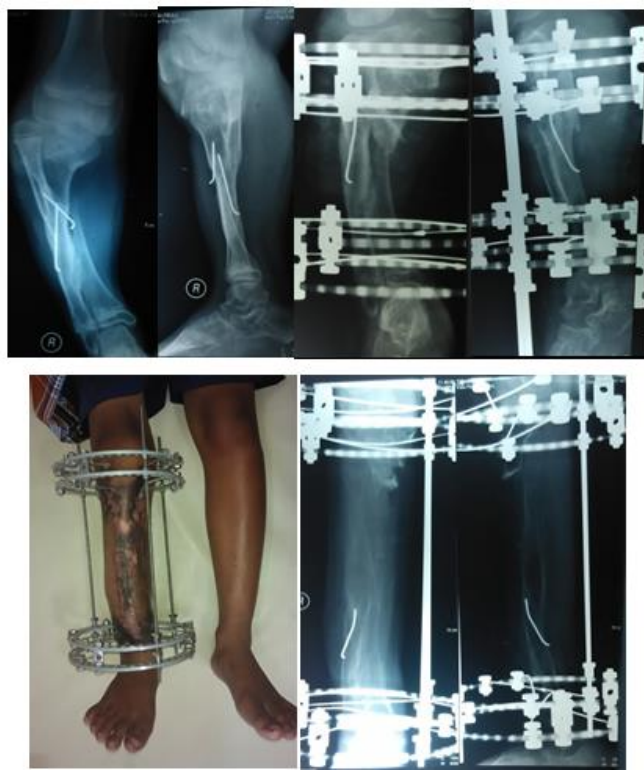
Laporan Kasus

Vol 7 No. 1, April 2018

ISSN 2460-8742

http://journal.unair.ac.id/ORTHO@journal-orthopaedi-and-traumatology-surabaya-media-104.html

Gambar 8. Kondisi awal Pasien 5 (Tn

AS/14 th) dengan severe deformity

(angulasi dan shortening) sebelum

dilakukan koreksi (gambar atas)

menunjukkan hasil yang bagus setelah

dilakukan koreksi gradual dengan Ilizarov device (gambar bawah)

\section{Komplikasi}

Komplikasi yang seringkali didapatkan pada pasien yang diterapi menggunakan Ilizarov system adalah pin tract infection. Penelitian yang dilakukan oleh Jean Claude et al (Dunedin, New Zealand 2000) pada 33 pasien yang diterapi menggunakan Ilizarov system, 90\% mengalami pintract infection yang dapat diterapi secara poliklinis menggunakan antibiotika oral, 4 kasus mengalami fixator problem (broken wire dan frame failure) yang membutuhkan koreksi framelfixator, 2 kasus mengalami komplikasi pada tulang berupa nonunion dan premature consolidation. Seorang pasien mengalami komplikasi berupa joint subluxation. Seorang pasien mengalami komplikasi berupa extensor hallucis longus weakness. ${ }^{2,9,10}$

Pada pasien yang dilakukan koreksi deformitas menggunakan Ilizarov system di RSUD Dr. Soetomo selama periode Januari 2013- Agustus 2017, dua kasus mengalami implant failure yang mengharuskan Ilizarov device diganti dengan alat lain dan 100 persen kasus terdapat pin tract infection yang semuanya dapat diterapi dengan perawatan luka rutin di poliklinik dan antibiotika oral. Terdapat 3 pasien yang mengalami joint stiffness dan 2 pasien mengalami fixator problem. Tidak didapatkan komplikasi berupa neurovaskuler injury pada seluruh pasien yang diterapi menggunakan ilizarov device.

\section{KESIMPULAN DAN SARAN}

Koreksi deformitas pada ekstremitas bawah dengan menggunakan Ilizarov system menunjukkan hasil yang cukup menjanjikan pada evaluasi menggunakan ASAMI scoring. Didapatkan hasil good untuk 9 pasien untuk skor tulang, dan 7 hasil exellent untuk skor fungsional dari total 9 pasien yang dievaluasi.

Gradual correction menggunakan Ilizarov device dapat digunakan sebagai salah satu pilihan untuk koreksi deformitas pada ekstremitas bawah, terutama pasien dengan deformitas yang berat (severe) dengan hasil yang menjanjikan.

\section{REFERENSI}

1. Noam Bor RM, Nimrod R. Ilizarov Method for Gradual Deformity Correction. Oper Tech Orthop. 2011;104-12.

2. Pathania VP, Sharma a. K, Joshi GR, John JT. Correction of lower limb deformities using Ilizarov's technique. Med J Armed Forces India. 
$2005 ; 61(4): 322-5$.

3. Tetsworth KD, Paley D. Deformity Correction By The Ilizarov Technique Dror Paley. In: Chapman MW, editor. Operative Orthopaedics. Second edi. Philadelphia: JB Lippincot; 1993. p. 883-948.

4. Rozbruch SR, Ilizarov S. Limb Lengthening and Reconstructive Surgery. New York: Informa; 2007.

5. Shahid M, Hussain A, Bridgeman P, Bose D. Clinical Outcomes of the Ilizarov Method After an Infected Tibial Non Union. Arch Trauma Res. 2013;2(2):71-5.

6. Aronson James, Rock Little and A. Current Concepts Review, Limb Lengthening, Skeletal Reconstruction, and Bone Transport With the Ilizarov
Method. J Bone Jt Surgery, Inc. 1997;79-b:1243-52.

7. Solomin, Leonid N M. The Basic Principles of External Fixation Using the Ilizarov Device. Verlag, Italia: Springer; 2008.

8. Bagnoli. The Ilizarov Method. Philadelphia: BC Deckers Inc; 1990.

9. Theis J. Correction of complex lower limb deformities by the Ilizarov technique : An audit of complications H Simpson and J Kenwright. Clin Orthop. 2000;8(1):67-71.

10. Yin Peng, et all. A Systematic Review and Meta-Analysis of Ilizarov Methods in the Treatment of Infected Nonunion of Tibia and Femur. Plos ONE Journal. 2015. P: 1-12. 